\title{
Wetland succession in a permafrost collapse: interactions between fire and thermokarst
}

\author{
I. H. Myers-Smith ${ }^{1, *}$, J. W. Harden ${ }^{2}$, M. Wilmking ${ }^{3}$, C. C. Fuller ${ }^{2}$, A. D. McGuire ${ }^{4}$, and F. S. Chapin III ${ }^{1}$ \\ ${ }^{1}$ Institute of Arctic Biology, 311 Irving I Bldg., University of Alaska Fairbanks, Fairbanks, Alaska, 99775, USA \\ ${ }^{2}$ US Geological Survey, 345 Middlefield Rd. MS 962, Menlo Park, California, 94025, USA \\ ${ }^{3}$ Institute for Botany and Landscape Ecology, Grimmer Strasse 88, Greifswald University, 17487, Greifswald, Germany \\ ${ }^{4}$ US Geological Survey, Alaska Cooperative Fish and Wildlife Research Unit, 214 Irving I Bldg., University of Alaska \\ Fairbanks, Fairbanks, Alaska, 99775, USA \\ "now at: Department of Biological Sciences, CW 405, Biological Sciences Centre, University of Alberta, Edmonton, Alberta, \\ T6G 2E9, Canada
}

Received: 1 November 2007 - Published in Biogeosciences Discuss.: 30 November 2007

Revised: 22 May 2008 - Accepted: 28 July 2008 - Published: 5 September 2008

\begin{abstract}
To determine the influence of fire and thermokarst in a boreal landscape, we investigated peat cores within and adjacent to a permafrost collapse feature on the Tanana River Floodplain of Interior Alaska. Radioisotope dating, diatom assemblages, plant macrofossils, charcoal fragments, and carbon and nitrogen content of the peat profile indicate $\sim 600$ years of vegetation succession with a transition from a terrestrial forest to a sedge-dominated wetland over 100 years ago, and to a Sphagnum-dominated peatland in approximately 1970. The shift from sedge to Sphagnum, and a decrease in the detrended tree-ring width index of black spruce trees adjacent to the collapse coincided with an increase in the growing season temperature record from Fairbanks. This concurrent wetland succession and reduced growth of black spruce trees indicates a step-wise ecosystem-level response to a change in regional climate. In 2001, fire was observed coincident with permafrost collapse and resulted in lateral expansion of the peatland. These observations and the peat profile suggest that future warming and/or increased fire disturbance could promote permafrost degradation, peatland expansion, and increase carbon storage across this landscape; however, the development of drought conditions could reduce the success of both black spruce and Sphagnum, and potentially decrease the long-term ecosystem carbon storage.
\end{abstract}

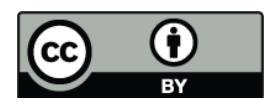

Correspondence to: I. H. Myers-Smith (imyerssmith@ualberta.ca)

\section{Introduction}

The spatial patterns of vegetation in the low lying flood plains of Interior Alaska are controlled by disturbances such as fire, permafrost degradation, flooding, and drainage. In particular, permafrost degradation is altering ecosystem structure and therefore, the capacity of northern wetlands to store carbon (Camill et al., 2001; Turetsky et al., 2002a). Because approximately one-quarter of the world's soil carbon is currently sequestered in boreal peatlands (Gorham, 1991; Apps et al., 1993; Turunen et al., 2002), degradation of permafrost could result in significant carbon emissions. Both carbon accumulation and methane emissions have been shown to increase in peatlands underlain by degrading permafrost as water tables increase and nutrients are released by the thawing soils (Robinson and Moore, 2000; Turetsky et al., 2000; Vitt et al., 2000; Camill et al., 2001; Turetsky et al., 2007). Permafrost thaw can also result in water body drainage (Yoshikawa et al., 2003; Jorgenson and Osterkamp, 2005; Riordan et al., 2006) potentially exposing wetlands to aerobic decomposition and carbon release. Different peatland communities store varying amounts of nutrients and maintain different soil environments (Camill and Clark, 1998). For these reasons, future carbon accumulation in permafrost peatlands will depend not only on plant and microbial responses to a warming climate, but on vegetation succession driven by fire and permafrost thaw.

Permafrost degradation observed over the last half century has altered ecosystem structure in boreal peatlands (Vitt et al., 2000; Camill et al., 2001; Jorgenson et al., 2001; Turetsky et al., 2002b; Christensen et al., 2004). In upland ecosystems permafrost thaw has resulted in patterned ground and

Published by Copernicus Publications on behalf of the European Geosciences Union. 

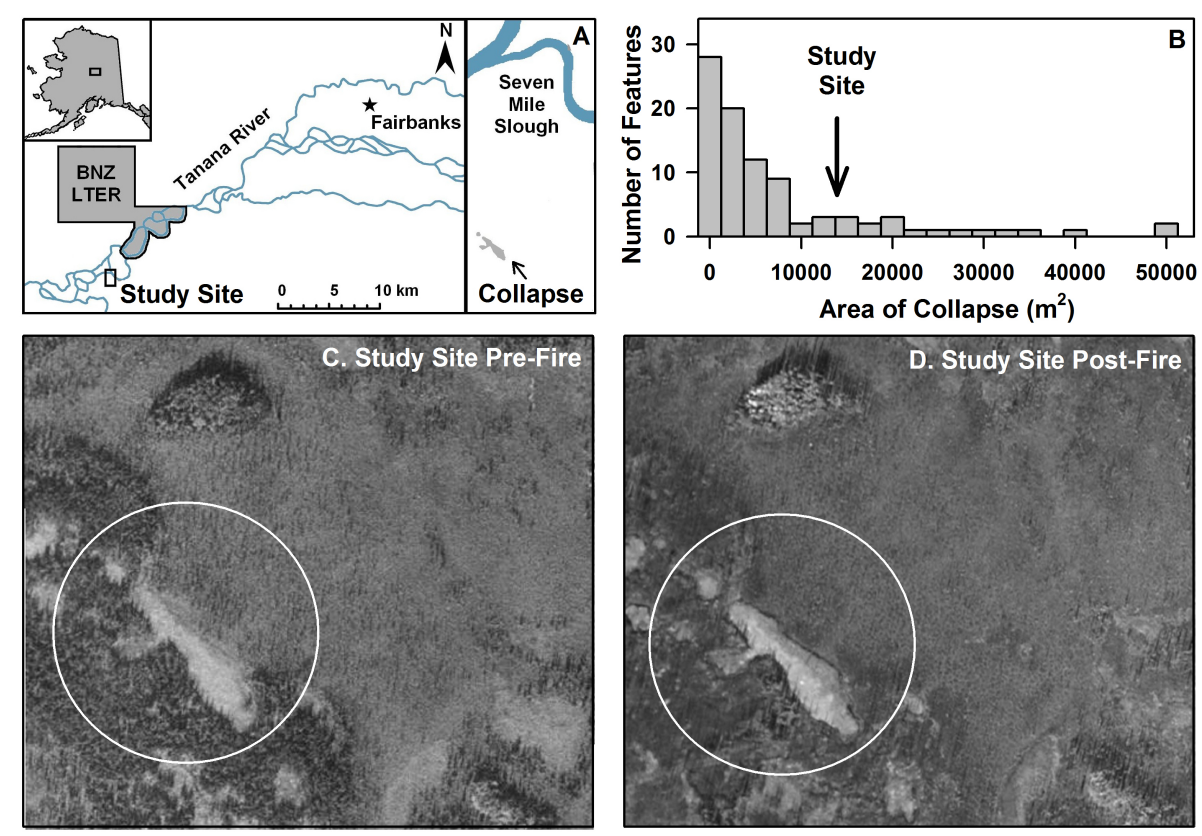

Fig. 1. Location of the study site, a permafrost collapse scar southwest of the Bonanza Creek experimental forest on the Tanana River

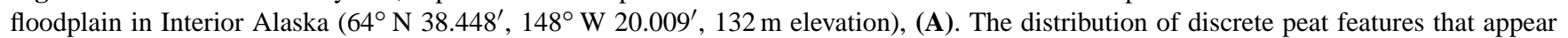
to be hydrologically isolated from the river, drainage channels or extensive fens in the $16 \mathrm{~km}^{2}$ area around the study site estimated using digitized aerial photos (Photoshop 7.0, Adobe, San Jose, CA, USA, $n=91)$, (B). Images show the collapse scar prior to (C) and after (D) the Survey-line Fire burned through the study site in late June 2001.

thermokarst pits (Osterkamp et al., 2000). In lowland ecosystems the loss of ice-rich permafrost has caused the conversion of forests to wetlands (Osterkamp et al., 2000; Jorgenson et al., 2001; Jorgenson and Osterkamp, 2005). Though air temperature influences the soil thermal regime, other factors such as ground ice content, soil texture, topography, slope, aspect, hydrology, winter snow fall and fire interact to determine rates of permafrost degradation (Osterkamp and Romanovsky, 1999; Jorgenson and Osterkamp, 2005). Discontinuous permafrost in Alaska is particularly sensitive to climate warming (Swanson, 1996) and warming of groundice has been observed at sites across the Interior (Osterkamp and Romanovsky, 1999). Since 1949, permafrost collapse has increased by $21 \%$ on the Tanana Floodplain of Interior Alaska (Jorgenson et al., 2001). By the end of the next century, permafrost could be eliminated from this landscape (Jorgenson et al., 2001).

Climate models project that the western boreal forest will experience significant warming over the next century (Stocks et al., 1998). Historical data indicate that between 1950 and 2000 annual surface temperatures in Interior Alaska have warmed by approximately $2^{\circ} \mathrm{C}$ (Keyser et al., 2000); however, during this period no clear trend in growing season precipitation has occurred (Keyser et al., 2000; Serreze et al., 2000). Warmer temperatures will increase evaporation and evapotranspiration; and therefore, peatlands are projected to experience drier conditions in the future (Wrona et al., 2004). Warmer and drier summers could result in an increase in the frequency and severity of stand-replacing fires (Harden et al., 2000), and therefore, the extent of permafrost degradation (Jorgenson et al., 2001; Camill, 2005). These changes in the disturbance regime could have an even larger effect on the release of greenhouse gas emissions than direct physiological responses of plants and microbes to a warming climate (Chapin et al., 2000).

To understand the interactions between fire and thermokarst on wetland succession, we examined a Sphagnum-dominated permafrost collapse in a fire-scarred Picea mariana (black spruce) forest. We hypothesize that fire initiated collapse expansion at this site. The loss of transpiration, decrease in summer albedo, and decrease in organic matter thickness after fire can trigger permafrost degradation (Jorgenson et al., 2001; Yoshikawa et al., 2003). Though, fire has been linked with permafrost degradation in the peatlands of Western Canada, most studies identify climate warming as the dominant trigger of collapse in the boreal zone (Thie, 1974; Zoltai, 1993; Kuhry, 1994; Camill and Clark, 2000; Jorgenson et al., 2001). Furthermore, the connections between climate, fire, and fire induced thaw have been little studied because we are still developing the best techniques to address these complex ecological interactions. 


\section{Methods}

\subsection{Study area}

In June 2001 an extensive fire, known as the Survey-Line fire burned south-west of Fairbanks, Alaska. In July 2001, one month following the fire, we established a transect from the centre of a permafrost collapse scar $\left(64^{\circ} \mathrm{N} 38.448^{\prime}, 148^{\circ} \mathrm{W}\right.$ $20.009^{\prime}, 132 \mathrm{~m}$ elevation) into the surrounding burned black spruce forest (Fig. 2) to monitor the ecological effects of this fire on a wetland permafrost landscape. Between our initial site survey and the summer of 2002, the periphery of the collapse feature had undergone a $6 \mathrm{~m}$ lateral expansion.

The field site is located southwest of the Bonanza Creek experimental forest in Interior Alaska, approximately $1 \mathrm{~km}$ south of the Tanana River (Fig. 1). Variable vegetation, hydrology, and topography from legacies of flooding, fire and thermokarst have created a complex landscape mosaic (Jorgenson et al., 2001). Approximately 5\% of the area between the active floodplain and the extensive fens to the south is collapse. In a $16 \mathrm{~km}^{2}$ area around the study site we identified 91 similar collapse features from aerial photographs which varied in size from $700-111400 \mathrm{~m}^{2}$. We surveyed the site on 5 August 2004, using a Topcon GTS 220 Series All-Weather Total Station (Topcon America Corporation, Paramus, NJ, USA), and found the area of the collapse to be $175 \mathrm{~m}$ long by $75 \mathrm{~m}$ wide or approximately $15000 \mathrm{~m}^{2}$ with a surface depression of up to $0.5 \mathrm{~m}$ (Fig. 2), slightly larger than the mean collapse size in the study region.

The study site is underlain by ice rich permafrost alluvial deposits of the Tanana River, and is located in an area of the floodplain that is not subject to groundwater upwelling (Jorgenson et al., 2001). Water level in wells ( $2 \mathrm{~m}$ screen depth) did not correlate significantly with river stage (National Water Information System, USGS) in the two years of this study (linear regression, inverse transformation, $\mathrm{p}$-value $=0.540$ ), suggesting that this site is isolated from the active floodplain of the Tanana River (Myers-Smith, 2005). The peatland is best characterized as a poor fen, receiving the majority of its water and nutrients from atmospheric sources (personal communication Jill Bubier, August 2001, Mount Holyoke University and Merritt Turetsky, Michigan State University).

In 2004, three ecological zones with distinct vegetation assemblages were observed along the transect, and were characterized as the peatland, moat and burn. The peatland was considered to be the Sphagnum mat, the moat, the area of recent soil subsidence, and the burn, the adjacent burned forest. The dominant vegetation types in the peatland were Sphagnum spp. (primarily $S$. riparium with increased S. squarrosum towards the margins of the collapse), Carex spp. (primarily C. canescens, C. aquatilis, and C. rostrata) and Eriophorum angustifolium. The vertical mean growth of the Sphagnum mat was $2.5 \pm 1.2 \mathrm{~cm}$ per year $( \pm \mathrm{SE}, n=19$, measured every $0.5 \mathrm{~m}$ along two transects from the edge to the centre of the permafrost collapse). The moat was dominated by Erio-

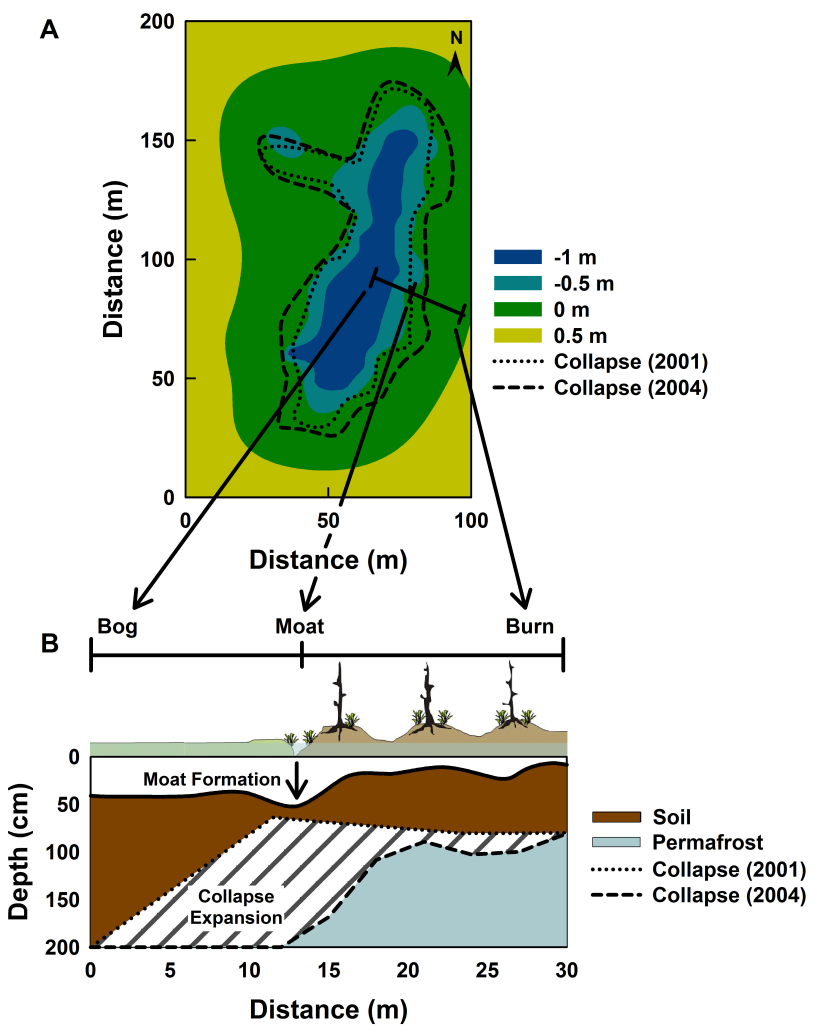

Fig. 2. Collapse expansion since the 2001 fire, illustrating the spatial extent of the collapse (A). The extent of the collapse in 2001 is indicated by the dotted line and in 2004 is indicated by the dashed line. Cross section of transect from centre of peatland to burn zone illustrating lateral subsidence and moat formation (B). The soil surface topography is indicated by the shades of colour in plot A and by the bold solid line in plot B. Frozen ground is represented by the blue polygon and the ground that has thawed since the fire is indicated by the hatched polygon. Cores were sampled along the transect at $0 \mathrm{~m}$ in the centre of the peatland, $12 \mathrm{~m}$ in the moat, and $27 \mathrm{~m}$ in the burned forest.

phorum vaginatum tussocks and Carex spp. Standing water was present in the moat throughout both the growing seasons of 2003 and 2004, allowing for the growth of aquatic vegetation. Prior to the Survey-Line Fire, the burn was a low-lying open-canopy Picea mariana forest with an understory of tussock vegetation. After the 2001 fire, the dominant vegetation types were Eriophorum vaginatum tussocks, Grasses, Betula spp., Salix spp., Potentilla palustris, Rhododendron groenlandicum, Vaccinium uliginosum, Vaccinium vitis-idaea and Chamaedaphne calyculata.

The peatland, moat and burn zones had unique soil profiles (Figs. 2b, 3 and 4). The peatland organic layer was $>0.5 \mathrm{~m}$ thick and the active layer was $>2 \mathrm{~m}$. The moat was the lowest portion of the transect, with an above surface water table for much of the growing season. The organic matter thickness was highly variable $(2-40 \mathrm{~cm})$ in the burn because of 


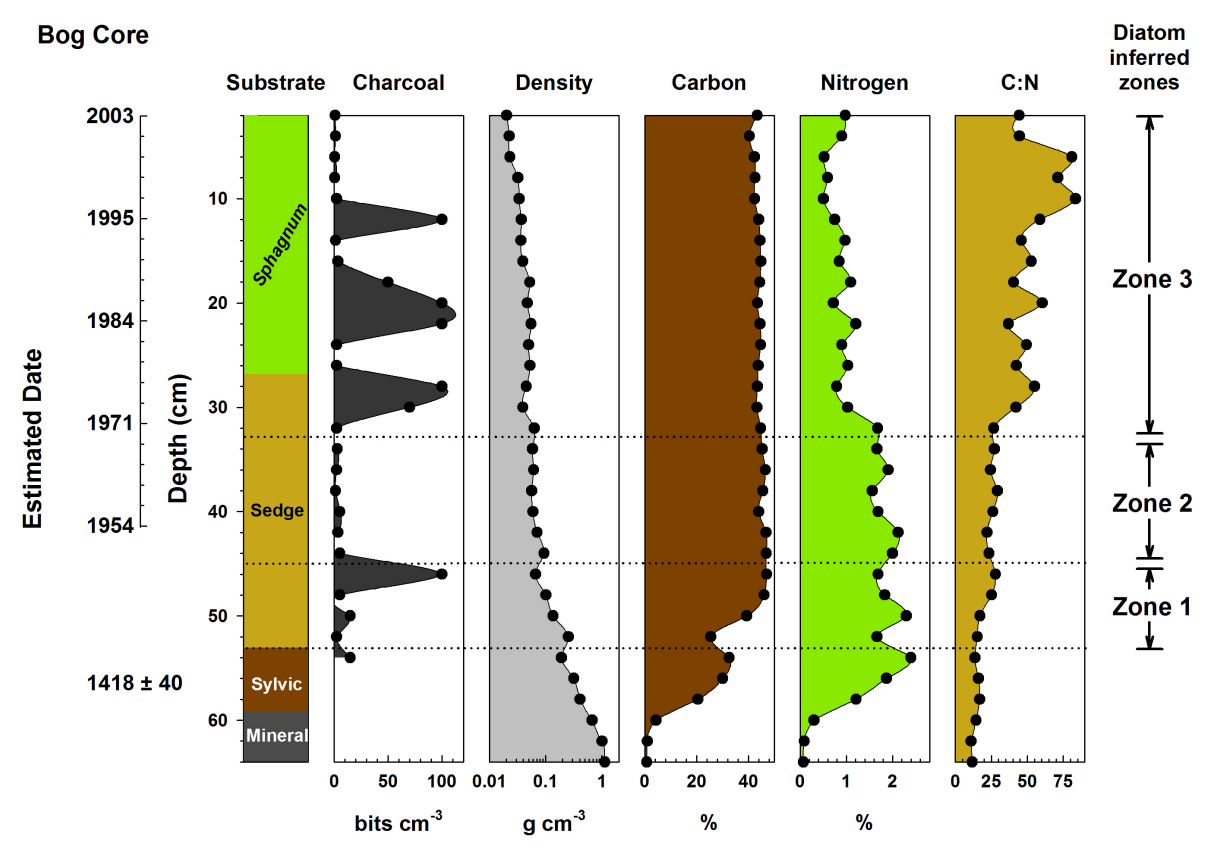

Fig. 3. Stratigraphy of a core from the centre of the peatland indicating charcoal remains, soil bulk density, \%C, \%N, and C:N. Dotted lines correspond to the diatom zones (Fig. 5). Estimated dates include the ${ }^{137} \mathrm{Cs}$ and ${ }^{210} \mathrm{~Pb}$ derived age model (Table 2) and the ${ }^{14} \mathrm{C}$ date for a piece of charcoal in the sylvic peat (Table 1).

tussock-hollow microtopography, patchy fuel consumption, and variable soil subsidence patterns. The maximum thaw depth in the burn was $\sim 80 \mathrm{~cm}$.

\subsection{Active layer depth}

To monitor changes in thaw depth, we pushed a $120 \mathrm{~cm}$ or $200 \mathrm{~cm}$ fiberglass frost probe into the soil until impenetrable ground was reached. The length of the probe inserted into the earth was considered to be the depth to frozen soil. We conducted three replicate measurements of the active layer every $3 \mathrm{~m}$ along both sides of the transect at each visit to the site (every one to two weeks throughout the growing season).

\subsection{Soil coring}

In March of 2003 we drilled $7.7 \mathrm{~cm}$ diameter-cores using a gasoline-powered permafrost corer from the centre of the peatland (peatland core, P26, $0 \mathrm{~m}$ along the transect, $64 \mathrm{~cm}$ long), the edge of the Sphagnum mat (moat core, M27, $12 \mathrm{~m}$ along the transect, $54 \mathrm{~cm}$ long) and within the burn (burn core, B22, $27 \mathrm{~m}$ along the transect, $45 \mathrm{~cm}$ long). We sampled three additional cores from the centre of the peatland (P1, P2, PS6, and PS5) for radio isotope dating (see Table 1 and Myers-Smith (2007) for further descriptions of cores at this site). Minimal rotation or deformation of soil layers and sediments occurred, because coring was conducted during winter when ambient temperatures were below freezing. Cores were stored frozen, until each were sectioned into $2 \mathrm{~cm}$ depth increments using a radial saw. Samples were sub-divided: half of the sample was preserved frozen, one quarter was air dried, used to calculate bulk density and then prepared for diatom analysis, the final quarter was used for physical descriptions, plant macrofossil identification, dating, and chemical analysis. We oven-dried the chemical analysis soil samples at $50-65^{\circ} \mathrm{C}$ and ground them in a tumbling ball mill for $2-$ 5 min, until a homogeneous powder was formed. These soil samples were analyzed for $\% \mathrm{C}$ and $\% \mathrm{~N}$ using a Carlo Erba EA1108 CHNS analyzer (CE Instruments, Milan, Italy) and a COSTECH ECS 4010 CHNS-O analyzer (Costech Analytical Technologies Inc., Valencia, CA, USA). Sample standard errors were $\pm 0.01 \%$ for nitrogen, $\pm 0.45 \%$ for carbon. We conducted gross-stratigraphic descriptions of plant microfossils and soils for each depth section of the three cores. We determined the dominant vegetation in the peat and moat core substrate, and sorted out peat fruiting bodies and leaves for isotopic analysis. We counted charcoal layers in the cores and estimated charcoal deposition by emptying dried samples of a known volume and depth (on mean $4.5 \mathrm{~cm}^{-3}$ ) over a $10 \mathrm{~cm} \times 10 \mathrm{~cm}$ grid and counting macroscopic charcoal fragments (greater than $0.05 \mathrm{~mm}$ in diameter) in each $\mathrm{cm}$ grid cell. Due to the limited size of the sample, we did not measure total charcoal abundance in the core. 


\section{Moat Core}

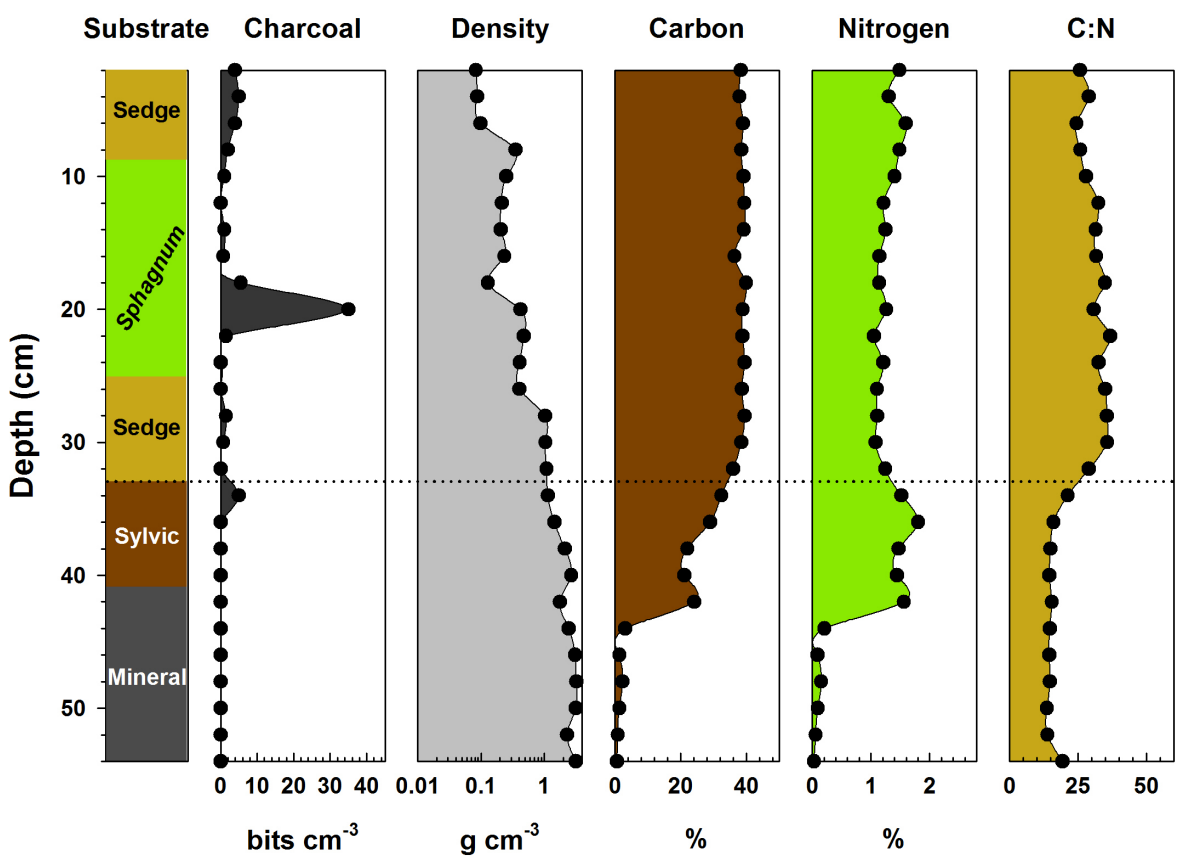

Fig. 4. Stratigraphy of a core from the moat portion of the transect indicating charcoal remains, soil density, \%C, \%N, and C:N. Dotted line corresponds to the transition from terrestrial organic matter to sedge-dominated peat.

Table 1. Radiocarbon results and the $\delta^{13} \mathrm{C}$ values used to correct for isotopic fractionation (Stuiver and Poach, 1977). Samples from the transect on the north (P26, P2, P1) and south (PS6 and PS5) sides of the collapse. The sample material included Sphagnum fruiting bodies (fb), bulk peat (bp), and charcoal (c). Analyzes were conducted at the Lawrence Livermore National Laboratory Centre for AMS (LLNL) or the UC Irvine W. M. Keck Carbon Cycle AMS facility (KCC).

\begin{tabular}{cccccccr}
\hline $\begin{array}{c}\text { Transect } \\
\text { Name }\end{array}$ & $\begin{array}{c}\text { Smpl. } \\
\text { ID }\end{array}$ & $\begin{array}{c}\text { Anal. } \\
\text { Loc. }\end{array}$ & $\begin{array}{c}\text { Depth } \\
(\mathrm{cm})\end{array}$ & $\begin{array}{c}\text { Smpl. } \\
\text { Mat. }\end{array}$ & $\begin{array}{c}\delta 13 \mathrm{C} \\
(\%)\end{array}$ & $\begin{array}{c}\delta 14 \mathrm{C} \\
(\%)\end{array}$ & $\begin{array}{c}\text { 14C age } \\
(\mathrm{BP})\end{array}$ \\
\hline North & P26.20 & LLNL & 20 & $\mathrm{fb}$ & -25 & $187.5 \pm 5.3$ & $<$ modern \\
North & P26.34 & LLNL & 34 & $\mathrm{fb}$ & -25 & $187.5 \pm 7.8$ & $<$ modern \\
North & P26.40 & LLNL & 40 & $\mathrm{fb}$ & -25 & $-18.0 \pm 4.4$ & $145 \pm 40$ \\
North & P26.54 & KCC & 54 & bp & $-26.7 \pm 0.15$ & $-36.3 \pm 1.8$ & $245 \pm 20$ \\
North & P26.56 & LLNL & 56 & bp & -25 & $-34.5 \pm 8.2$ & $280 \pm 70$ \\
North & P26.56 & KCC & 56 & bp & $-26.6 \pm 0.15$ & $-47.1 \pm 1.6$ & $335 \pm 15$ \\
North & P26.56 & LLNL & 56 & c & -25 & $-70.1 \pm 4.1$ & $585 \pm 40$ \\
North & P26.58 & KCC & 58 & bp & $-27.2 \pm 0.15$ & $-63.7 \pm 1.7$ & $475 \pm 15$ \\
North & P2.60 & KCC & 60 & bp & $-27.2 \pm 0.15$ & $-27.1 \pm 1.6$ & $165 \pm 15$ \\
North & P1.65 & KCC & 65 & bp & $-27.2 \pm 0.15$ & $-39.3 \pm 1.6$ & $270 \pm 15$ \\
South & PS6.75 & KCC & 75 & bp & - & - & $505 \pm 40$ \\
South & PS5.77 & KCC & 77 & bp & - & - & $80 \pm 40$ \\
\hline
\end{tabular}

\subsection{Diatoms}

Diatoms have been shown to be a useful indicator of peatland succession, local hydrology, and fire disturbance (Kienel et al., 1999; Moser et al., 2000; Rühland et al., 2000) and can be more sensitive to changes in water chemistry than the com- monly used peat indicators such as pollen and macrofossils (Rühland et al., 2000). In this study, we employed diatom analysis to indicate changes in $\mathrm{pH}$ and nutrients in the aquatic environment. To survey the diatom community, we processed the three cores from the peatland, moat and burn that were sampled every $2 \mathrm{~cm}$ by depth using methods described 
by the Queen's University Paleoecological Environmental Assessment and Research Laboratory (PEARL) and personal communications (K. Rühland, J. P. Smol, J. Barron, and M. Peterson). We digested the dried material, consisting of organic matter with varying amounts of sediment, in Kjeldahl digestion tubes in a heating block. We used 50:50 solution by molecular weight of concentrated $\mathrm{H}_{2} \mathrm{SO}_{4}$ and $\mathrm{HNO}_{3}$ and digested for 3 days at $95^{\circ} \mathrm{C}$ or until the disappearance of all organic matter. We diluted the resulting solution with deionized water to a neutral $\mathrm{pH}$. We mounted the samples using the Pleurax high refractive index mounting medium (prepared by W. Dailey, University of Pennsylvania). To determine the prevalence of the different diatoms, we counted 400 valves (or for one sparse sample, four slides) for each sample. Partial diatoms were only counted when more than half of the valve remained and the genus was clearly distinguishable. We identified samples according to Foged (1981), Krammer and Lange-Bertalot (1986-1991), and personal communications with K. Rühland and M. Peterson. All diatom valves were keyed out to genus, and when we were able we identified species, we refer to these taxa together (genus and species) as diatom categories (see Fig. 8).

\subsection{Treerings}

We used dendrochronology to link the below ground data to above ground observations of the response of this system to collapse. Tree-ring analysis provides a record of the response of the black spruce trees to changing climate and ongoing thermokarst, allowing for speculation about the response of this landscape to future climate change. We harvested twenty-one fire-killed tree cross-sections from the margin of the collapse and in the surrounding burn in the growing season of 2004 (Wilmking and Myers-Smith, 2008). We measured ring width (sliding stage, Velmex Inc., Bloomfield, NY, USA, resolution: $0.001 \mathrm{~mm}$ ) for two radial transects of the tree cross-sections, which showed the least amount of compression wood. To build site chronologies, we first crossdated tree ring series with the program Cofecha (R. Holmes, Laboratory of Tree Ring Research, University of Arizona) and adjusted possible dating errors and then standardized ring-widths with the program ARSTAN using traditional negative exponential or straight line fits (R. Holmes, Laboratory of Tree Ring Research, University of Arizona) to remove the age-related variation in growth rate. These site chronologies were used for climate-growth correlations with temperature and precipitation data from a composite of climate data from the University Experiment Station (1906-1947) and Fairbanks International Airport (1948-2000; Wilmking et al., 2004). In addition, we recorded the presence and amount of compression-wood for each year in the disk, an indicator of leaning which is interpreted to be related to frost-heaving and permafrost collapse (Camill and Clark, 1998).

\subsection{Core dating}

To estimate the age of peat deposits we utilized AMS radiocarbon, ${ }^{210} \mathrm{~Pb}$ and ${ }^{137} \mathrm{Cs}$ isotopic dating techniques (Oldfield et al., 1995; Turetsky et al., 2004, ; Table 1). We used the ${ }^{210} \mathrm{~Pb}$ and ${ }^{137} \mathrm{Cs}$ data to develop three age estimate models. Two mass accumulation rates (MAR, $\mathrm{g} \mathrm{cm}^{-2} \mathrm{yr}^{-1}$ ) derived from unsupported ${ }^{210} \mathrm{~Pb}$ are the constant flux-constant accumulation rate (CF-CS) and the constant rate of supply (CRS) methods (Appleby and Oldfield, 1992). The CF-CS MAR is derived from the slope of the $\ln$ (unsupported ${ }^{210} \mathrm{~Pb}$ ) versus cumulative dry mass. The CRS method (CRS) assumes a constant rate of supply of unsupported ${ }^{210} \mathrm{~Pb}$ and calculates the MAR of each successive layer by creating a ratio of the unsupported ${ }^{210} \mathrm{~Pb}$ activity (decays per minute $(\mathrm{dpm}) \times \mathrm{cm}^{-2}$ ) below the layer to the total integrated activity to derive the age of the layer. The ${ }^{137} \mathrm{CS}-\mathrm{MAR}$ is derived by assigning dates of 1964 to the peak activity in ${ }^{137} \mathrm{Cs}$ $(34 \mathrm{~cm})$ and 1952 to the depth of first occurrence of measurable ${ }^{137} \mathrm{Cs} 1952$ assuming a constant mass accumulation rate at this depth range (Fuller et al., 1999). In Table 2, we report the mean and range (minimum and maximum) of these three age models. The ${ }^{137} \mathrm{Cs}$ and ${ }^{210} \mathrm{~Pb}$ ages agree to within 10 to 15 years, with the divergence likely due to differing mobility in the deposit.

Sphagnum fruiting bodies, charcoal and bulk peat samples from the core collected from centre of the peatland were analyzed for ${ }^{14} \mathrm{C}$ using accelerator mass spectrometry (Table 1; AMS, 1.5 SDH.1 Pelletron Accelerator, National Electrostatics Corporation, Middleton, Wisconsin, USA) at the Lawrence Livermore National Laboratory Centre for AMS and the UC Irvine W. M. Keck Carbon Cycle AMS facility. Peat samples from 2, 8, 20, and 24-54 cm-depths were analyzed for ${ }^{137} \mathrm{Cs}$, total ${ }^{210} \mathrm{~Pb}$ and ${ }^{226} \mathrm{Ra}$ activity by gamma spectrometery at the USGS Sediment Radioisotope Laboratory in Menlo Park (Fuller et al., 1999).

\subsection{Statistical analysis and data reporting}

We determined diatom-delineated zones using constrained cluster analysis by information content (CONIIC) by the program Psimpoll 3.01 (K. D. Bennett, Uppsala University). We performed regressions in JMP IN 5.1.2 (SAS Institute Inc., Cary, NC, USA). Field and analytical data are reported for all sites and samples at the Bonanza Creek LTER website http://www.lter.uaf.edu listed under the investigator Isla Myers-Smith. Archive samples are stored at US Geological Survey at Menlo Park.

\section{Results}

\subsection{Age estimates}

Ages as a function of depth were estimated for the top $54 \mathrm{~cm}$ of the peatland core from radioisotope profiles with 
Table 2. Sample results for ${ }^{137} \mathrm{Cs}$ and ${ }^{210} \mathrm{~Pb}$ (mean $\pm \mathrm{SE}$ ), the isotope derived age model (mid point of the 3 age estimates \pm range), and estimated carbon accumulation for the peatland core. The supported ${ }^{210} \mathrm{~Pb}$ activity, defined by the ${ }^{226} \mathrm{Ra}$ activity, was determined on each interval by subtracting the ${ }^{226} \mathrm{Ra}$ activity, defined as the average of the measured ${ }^{214} \mathrm{~Pb}$ and ${ }^{214} \mathrm{Bi}$ from total ${ }^{210} \mathrm{~Pb}$. In many intervals no correction was made because the measured ${ }^{226} \mathrm{Ra}$ was less than the method detection limit of $0.3 \mathrm{dpm} / \mathrm{g}$.

\begin{tabular}{ccccccc}
\hline $\begin{array}{c}\text { Depth } \\
(\mathrm{cm})\end{array}$ & $\begin{array}{c}{ }^{137} \mathrm{Cs} \\
(\mathrm{pCi} / \mathrm{gm})\end{array}$ & $\begin{array}{c}{ }^{210} \mathrm{~Pb} \\
\text { Total }\end{array}$ & $\begin{array}{c}\text { Sup. Act. } \\
226 \mathrm{Ra}\end{array}$ & $\begin{array}{c}\text { Unsup. } \\
210 \mathrm{~Pb}\end{array}$ & $\begin{array}{c}\text { Age } \\
\text { Model }\end{array}$ & $\begin{array}{c}\mathrm{C} \mathrm{Acc.}^{-2} \\
\left(\mathrm{kgC} \mathrm{m}^{-2}\right)\end{array}$ \\
\hline 2 & $0.26 \pm 0.26$ & $8.48 \pm 4.41$ & $<0.3$ & $8.48 \pm 4.41$ & $2003 \pm 0$ & 0.2 \\
8 & $0.16 \pm 0.11$ & $9.32 \pm 1.76$ & $0.55 \pm 0.39$ & $8.77 \pm 1.47$ & $1999 \pm 2$ & 0.8 \\
10 & $0.15 \pm 0.13$ & $5.61 \pm 2.20$ & $<0.3$ & $5.61 \pm 2.20$ & $1998 \pm 3$ & 1.1 \\
12 & $0.24 \pm 0.13$ & $4.68 \pm 2.20$ & $0.41 \pm 0.47$ & $4.27 \pm 1.64$ & $1996 \pm 4$ & 1.4 \\
14 & $0.12 \pm 0.14$ & $9.06 \pm 2.38$ & $0.70 \pm 0.54$ & $8.37 \pm 1.71$ & $1994 \pm 5$ & 1.7 \\
16 & $<0.07$ & $8.97 \pm 2.87$ & $0.71 \pm 0.67$ & $8.27 \pm 1.88$ & $1992 \pm 6$ & 2.0 \\
20 & $0.40 \pm 0.13$ & $8.20 \pm 2.11$ & $0.41 \pm 0.47$ & $7.79 \pm 2.16$ & $1987 \pm 8$ & 2.9 \\
24 & $0.31 \pm 0.07$ & $5.16 \pm 1.08$ & $<0.3$ & $5.16 \pm 1.08$ & $1981 \pm 11$ & 3.8 \\
26 & $0.51 \pm 0.08$ & $4.10 \pm 1.15$ & $<0.3$ & $4.10 \pm 1.15$ & $1979 \pm 12$ & 4.3 \\
28 & $0.62 \pm 0.08$ & $4.97 \pm 1.14$ & $<0.3$ & $4.97 \pm 1.14$ & $1976 \pm 14$ & 4.7 \\
30 & $1.66 \pm 0.10$ & $4.48 \pm 1.89$ & $<0.3$ & $4.48 \pm 1.89$ & $1974 \pm 14$ & 5.0 \\
32 & $2.75 \pm 0.12$ & $5.48 \pm 1.33$ & $<0.3$ & $5.48 \pm 1.33$ & $1971 \pm 15$ & 5.5 \\
34 & $2.78 \pm 0.10$ & $8.11 \pm 1.16$ & $<0.3$ & $8.11 \pm 1.16$ & $1967 \pm 15$ & 6.1 \\
36 & $1.46 \pm 0.08$ & $5.48 \pm 1.09$ & $<0.3$ & $5.48 \pm 1.09$ & $1964 \pm 17$ & 6.6 \\
38 & $2.03 \pm 0.09$ & $5.59 \pm 1.12$ & $<0.3$ & $5.59 \pm 1.12$ & $1961 \pm 18$ & 7.1 \\
40 & $1.66 \pm 0.10$ & $6.52 \pm 1.35$ & $<0.3$ & $6.52 \pm 1.35$ & $1958 \pm 19$ & 7.6 \\
42 & $0.95 \pm 0.10$ & $4.30 \pm 1.52$ & $<0.3$ & $4.30 \pm 1.52$ & $1954 \pm 21$ & 8.3 \\
44 & $1.08 \pm 0.09$ & $3.70 \pm 1.31$ & $<0.3$ & $3.70 \pm 1.31$ & $1950 \pm 22$ & 9.1 \\
46 & $1.08 \pm 0.08$ & $2.06 \pm 1.12$ & $<0.3$ & $2.06 \pm 1.12$ & $1945 \pm 24$ & 9.8 \\
48 & $1.19 \pm 0.07$ & $2.84 \pm 1.05$ & $<0.3$ & $2.84 \pm 1.05$ & $1941 \pm 26$ & 10.7 \\
50 & $1.29 \pm 0.09$ & $4.36 \pm 1.24$ & $<0.3$ & $4.36 \pm 1.24$ & $1935 \pm 29$ & 11.7 \\
52 & $0.27 \pm 0.03$ & $1.98 \pm 0.52$ & $1.16 \pm 0.12$ & $0.81 \pm 0.53$ & $1915 \pm 52$ & 13.0 \\
54 & $<0.07$ & $1.48 \pm 0.41$ & $0.86 \pm 0.09$ & $0.62 \pm 0.42$ & $1889 \pm 85$ & 14.2 \\
\hline & & & & & &
\end{tabular}

correction for compaction within the core (Table 2). The radiocarbon age estimates for the sylvic (tree derived) peat samples in the peatland core are $335 \mathrm{yr} B P$ at $56 \mathrm{~cm}$, $475 \mathrm{yr} \mathrm{BP}$ at $58 \mathrm{~cm}$, and $585 \mathrm{yr} \mathrm{BP}$ for a piece of charcoal at $56 \mathrm{~cm}$ depth. The age estimate for a sedge peat sample from $54 \mathrm{~cm}$ in the peatland core is 245 years before present (yr BP).

\subsection{Core stratigraphy}

Stratigraphic analyses of the sediment cores from the centre of the peatland and moat, include records of carbon, nitrogen, charcoal, soil density, and vegetation assemblage (Figs. 3 and 4). Soil bulk density and the percent nitrogen were variable with depth through both cores; however, following peaks in charcoal deposits, greater bulk density corresponded with lower $\mathrm{C}: \mathrm{N}$.

We found three distinct organic matter substrates in the core from the centre of the peatland: sylvic peat from 53$59 \mathrm{~cm}$, sedge-dominated peat from $27-53 \mathrm{~cm}$, and Sphagnum-dominated peat from 0-27 cm (Fig. 3). We identified four organic matter substrates in the moat core: sylvic peat from $33-41 \mathrm{~cm}$, sedge-dominated peat from $25-33 \mathrm{~cm}$,
Sphagnum-dominated peat from $9-25 \mathrm{~cm}$ and a return to sedge-dominated peat from $0-8 \mathrm{~cm}$ (Fig. 4). Diatom assemblages were very well preserved in the peat sediments in the top $48 \mathrm{~cm}$ of the peatland core, and the top $44 \mathrm{~cm}$ of the moat core; however, at the base of both cores diatoms were sparse, many of the valves were broken and sediment obscured the slides. The diatom assemblages for the peatland core delineated with CONIIC into three zones that agreed loosely with the three substrates: sylvic, sedge-dominated, and Sphagnum-dominated peat (Fig. 5); however, in the moat core the patterns are less clear (Fig. 6).

\subsection{Peatland core zone 1}

Zone $1(53-59 \mathrm{~cm})$ consisted of charred sylvic peat and well decomposed sedges. Bulk density in this region of the core was high (0.1-1.1 $\left.\mathrm{g} \mathrm{cm}^{-3}\right)$ and $\mathrm{C}: \mathrm{N}$ ratios were low (11-28). The diatom species Pinnularia spp., Hantzschia amphioxys var. major, Eunotia praerupta, Navicula amphibola, Stauroneis phoenicentreon were present in low densities at the bottom of the sedge-dominated portion of the core. The diatom assemblages in zone 1 were similar to that at $4 \mathrm{~cm}$ depth in the terrestrial soil core from the adjacent burned 


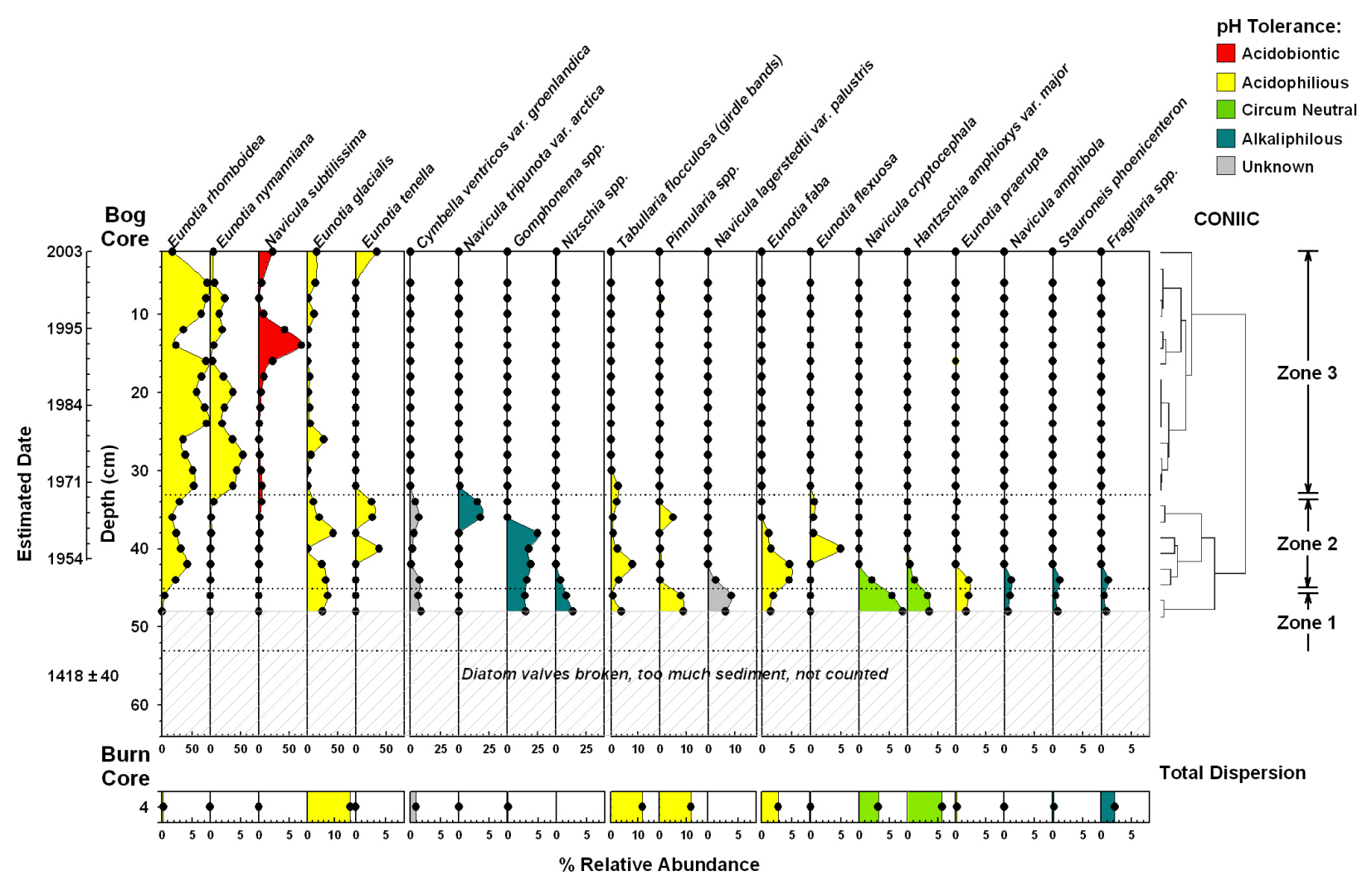

Fig. 5. The percent relative abundance of key diatom species/genera assemblages for the peatland core. Diatom-delineated zones were determined using constrained cluster analysis by information content (CONIIC). We consider the first diatom zone to begin at $53 \mathrm{~cm}$ where the sedge-dominated substrate begins; however, diatoms were not counted below $48 \mathrm{~cm}$ due to a high proportion of broken valves, residual organic matter and inorganic sediment on the slides. The diatom taxa are presented from most dominant to least dominant from left to right across the figure, the colour of the area under each curve corresponds to the $\mathrm{pH}$ tolerance of each diatom (see legend). The abundance of diatom species in the terrestrial soil core at $4 \mathrm{~cm}$ is included below the peatland core data. Estimated dates include the $\mathrm{Cs}$ and ${ }^{210} \mathrm{~Pb}$ derived age model (Table 2) and the ${ }^{14} \mathrm{C}$ date for a piece of charcoal in the sylvic peat (Table 1 ).

forest (Fig. 7), with high densities of Pinnularia spp., Eunotia Faba, Navicula cryptocephala, Fragilaria spp., and the aerophilic species Hantzschia amphioxys var. major. Conspicuous ( $\sim 0.5 \mathrm{~mm}$ in diameter) charcoal pieces were found in the sylvic peat deposits, and a peak of charcoal was found at $46 \mathrm{~cm}$ depth just prior to the transition to the second diatom zone.

\subsection{Peatland core zone 2}

Zone $2(27-53 \mathrm{~cm})$ was composed of sedge-dominated peat. Bulk densities were less in this portion of the core (0.06$0.09 \mathrm{~g} \mathrm{~cm}^{-3}$ ); however, C:N ratios remained low (22-29). The diatom species Gomphonema spp., Cymbella ventricosa var. groenlandica, Navicula tripunctata var. arctica, and Nitzchia spp. were common in this middle portion of the peatland core. A peak of E. rhomboidea, Tabellaria flocculosa (girdle bands), and $E$. faba at $42 \mathrm{~cm}$ coincided with a peak in \% nitrogen. A peak of E. tenella, C. ventricosa, N. tripunctata, Pinnularia spp., and E. flexuosa at $36 \mathrm{~cm}$ corresponded to another peak in bulk density and $\%$ nitrogen. Estimated carbon accumulation averaged $171 \pm 42 \mathrm{gC} \mathrm{m}^{-2} \mathrm{y}^{-1}$ (or $6 \pm 2 \mathrm{~mm} \mathrm{y}^{-1}, \pm$ range) for this sedge-dominated zone.

\subsection{Peatland core zone 3}

Zone $3(0-27 \mathrm{~cm})$ was made up of primarily Sphagnumdominated peat. In this portion of the transect bulk densities were lowest $\left(0.02-0.06 \mathrm{~g} \mathrm{~cm}^{-3}\right)$ and $\mathrm{C}: \mathrm{N}$ ratios were highest (27-84). Three peaks in charcoal abundance were found during this zone of the core (Fig. 3). A shift in the diatom assemblage was initiated $6 \mathrm{~cm}$ beneath the shift to Sphagnum-domination at $33 \mathrm{~cm}$ (Fig. 5) in the macrofossil record. In the uppermost Sphagnum-dominated portion of the core (zone 3), Eunotia rhomboidea, E. nymanniana, E. glacialis, and Navicula subtilissima were prevalent. Peaks in specific diatom abundance (Fig. 5) often correlated with specific physical and chemical characteristics of 


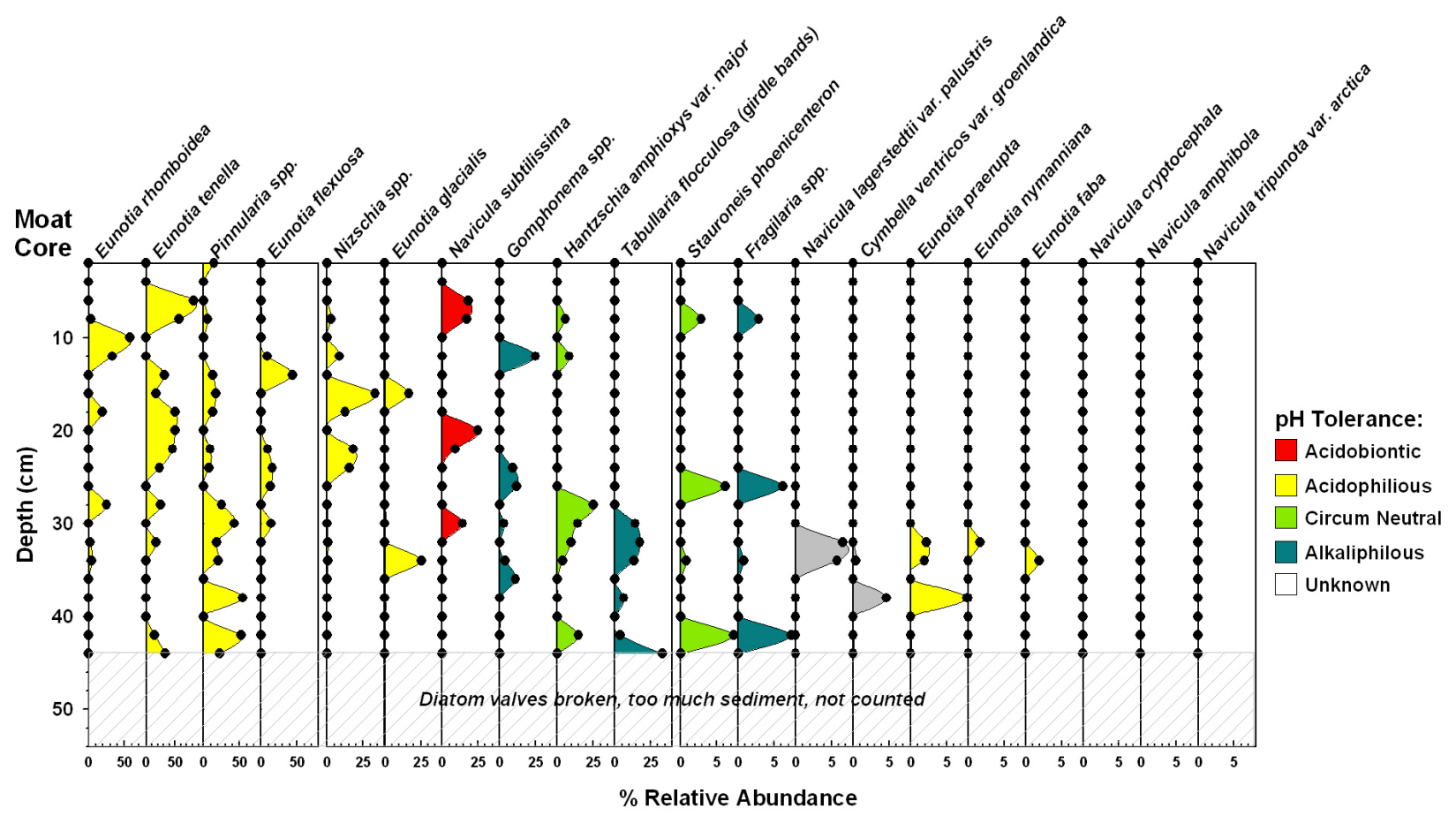

Fig. 6. The percent relative abundance of key diatom species/genera assemblages for the moat core. Diatoms were not counted below $44 \mathrm{~cm}$ due to sparse diatom densities, a high proportion of broken valves, residual organic matter and inorganic sediment on the slides. The diatom taxa are presented from most dominant to least dominant from left to right across the figure, the colour of the area under each curve corresponds to the $\mathrm{pH}$ tolerance of each diatom (see legend).

the core. For example, the abundance of E. nymanniana responded positively to charcoal deposits and tracked bulk density (cross correlation, $r=0.62$, p-value $<0.003, d=-1$; Figs. 3 and 5). Estimated carbon accumulation averaged $172 \pm 154 \mathrm{gC} \mathrm{m}^{-2} \mathrm{y}^{-1}$ (or $11 \pm 7 \mathrm{~mm} \mathrm{y}^{-1}$, \pm range) for the Sphagnum dominated portion of the core.

\subsection{Treerings}

For the period from 1930 to 2000 , we found a negative relationship between growing season air temperature and the detrended tree-ring width index for black spruce in the terrestrial portion of the landscape (Fig. 8; Wilmking and MyersSmith, 2008) The tree ring width index for trees growing in the wetter environment at the margins of the collapse feature showed weaker relationship with temperature (linear regression, $\left.R^{2}=0.04, P=0.11\right)$. Compression-wood was observed in 14 of the 21 trees sampled.

\section{Discussion and conclusions}

Diatom assemblages, plant macrofossils and soil chemistry in the sylvic soil layers from both peatland and moat cores indicate that a terrestrial forest pre-dated the initiation of the collapse. The $\% \mathrm{C}, \% \mathrm{~N}, \mathrm{C}: \mathrm{N}$, and density in the organic mat- ter above the mineral horizon was similar in all of the cores from the transect, and woody peat and charcoal were found at the base of both the peatland and moat cores. The diatom assemblage above the sylvic peat layer in the peatland and moat cores were analogous to assemblages observed in modern soils from the terrestrial black spruce forest adjacent to the peatland. This assemblage of alkaliphilous to $\mathrm{pH}$ neutral, salt tolerant, and mesotraphentic to eutraphentic (tolerant of nutrient enrichment) taxa of diatoms (Pinnularia spp., Navicula amphibola, Stauroneis phoenicentreon) and the aerophilic diatom taxon Hantzschia amphioxys var. major indicate less acidic, nutrient rich soil (Van Dam et al., 1994).

Radio isotope dating of the transition from (burned) sylvic organic matter to sedge-dominated peat layers in the peatland and moat cores help to reveal the history of this permafrost collapse. Though uncertain, the radio isotope age estimates suggests that the collapse likely formed over 100 years ago (Figs. 3 and 5), from a landscape similar to the present-day black spruce forest. The charcoal date of $585 \mathrm{yr}$ BP in the sylvic peat may not represent the age at the time of the collapse, because this soil likely underwent cryoturbation, organic matter loss from fire, and mixing from root growth, combining older soil layers with younger. There are no dates for the older sedge dominated peat just above the sylvic peat; 
ZONE 3: Sphagnum-dominated

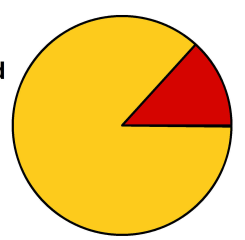

ZONE 2:

Sedge-dominated

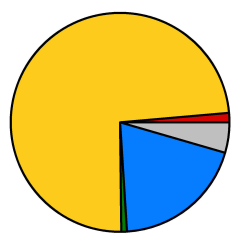

ZONE 3:

Terrestrial Sedge

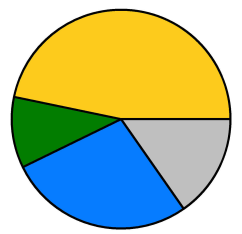

Modern:

Terrestrial Soil
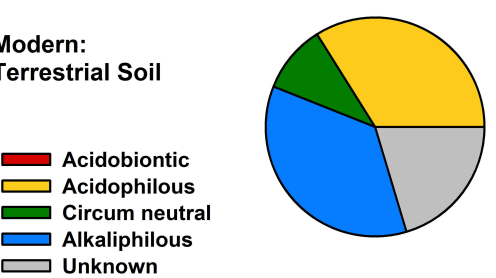
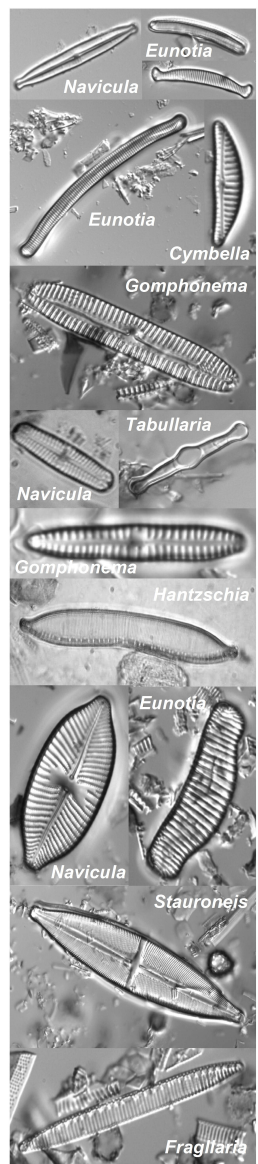

Fig. 7. Diatom species assemblages for the peatland, moat and terrestrial soil cores classified by $\mathrm{pH}$ tolerance. Photographs indicate the dominant diatom species found with depth in the core, with the diatoms found in the Sphagnum-dominated zone at the top, the sedge-dominated zone in the centre, and the sylvic zone at the base of the figure.

however, this portion of the peatland core has a lower $\mathrm{C}: \mathrm{N}$ ratio and likely a much slower peat accumulation rate. The dating estimate for the youngest portion of the core is also imprecise because there is uncertainty and error associated with ${ }^{210} \mathrm{~Pb}$ and ${ }^{137} \mathrm{Cs}$ dating technique.

During the initial collapse, the sedge-dominated zone (zone 2) was colonized by circum-neutral, mesotraphentic (indifferent to trophic conditions) and epiphytic (growing on plants, rather than planktonic) diatom species. This is consistent with a nutrient rich peatland environment found in sedge-dominated ecosystems today (Rühland et al., 2000). The dominant vegetation, diatom assemblage, and peat chemistry changed at the beginning of zone 3 (between 26 and $32 \mathrm{~cm}$ depth in the core). The shift in the diatom assemblage occurred around $1969 \pm 15 \mathrm{yrs}$ and predated the shift from sedge to Sphagnum peat and C:N ratio that occurred around $1978 \pm 13$ yrs. Diatoms in Siberia have previously

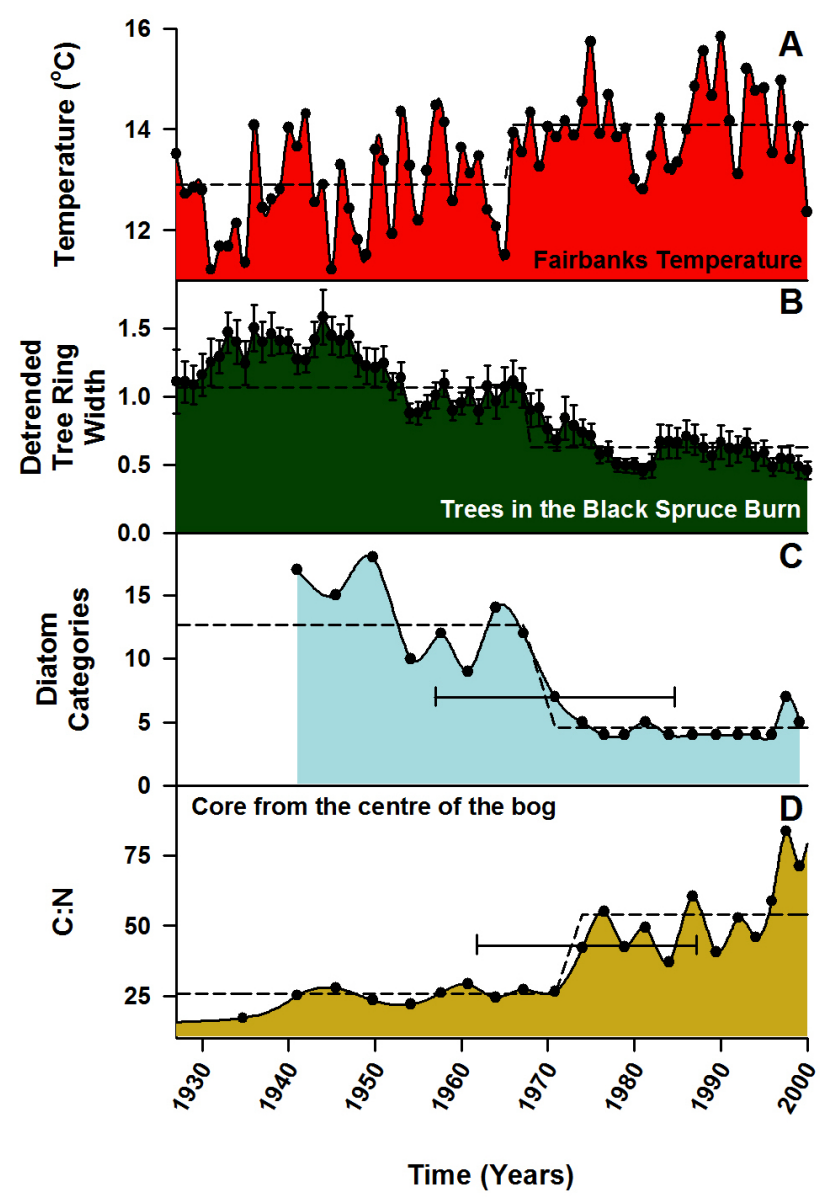

Fig. 8. Growing season temperature (May, June, July and August) from a composite of University Experiment Station (1906-1947) and Fairbanks International Airport (1948-2000, Wilmking and Myers-Smith, 2008), (A) detrended tree-ring width index for black spruce trees in the ecosystem surrounding the collapse (mean $\pm \mathrm{SE}$, $n=11$, Wilmking and Myers-Smith, 2008), (B) number of diatom categories (diatom genus or species, error bar indicates the error in the age estimate at 1965), (C) and the ratio of carbon to nitrogen (error bar indicates the error in the age estimate at 1965), (D). Dashed lines indicate the shift in each of the data sets.

been shown to respond first to changes in peatland chemistry and then secondarily to changes in bryophytes (Rühland et al., 2000). In our study, the shift in diatom assemblage may be in response to the shift in temperature in the Fairbanks region (Fig. 8), which seemed to be part of a synoptic scale shift to warm and dry conditions since 1974 (Barber et al., 2004). Since a sedge-dominated wetland is consistent with wetter, more nutrient rich conditions (Zoltai, 1995), the change to Sphagnum-domination suggests that conditions became drier, more acidic and/or more nutrient poor in the collapse perhaps as a result of consecutive warm growing seasons in the late 1970s. 
Diatom assemblages and plant macrofossils comprise the most recent zone of the peatland core (zone 3) and indicate that the peatland collapse has become an acidic poor fen within the past 3 decades (Fig. 6). This Sphagnumdominated portion of the core contained predominantly acidophilous (mainly occurring below pH 7) Eunotia spp., and a peak in the acidobiontic (optimal occurrence at $\mathrm{pH} 5.5$; Van Dam et al., 1994) species Navicula subtilissima at $14 \mathrm{~cm}$, suggesting a period of low $\mathrm{pH}$ during the recent history of the peatland environment.

The shorter organic profile at the edge of the peat mat (Myers-Smith, 2007) and the single charcoal peak in the moat core may indicate that the sylvic organic matter in the moat core is younger than in the peatland core, suggesting a lateral, outward expansion of the permafrost collapse. The moat core also showed less clear changes in diatom assemblages with depth. Acidophilious diatoms were found throughout the core. The eutraphentic Stauroneis phoenicenteron and aerophilic Hantzschia amphioxys var. major were counted at $8 \mathrm{~cm}$ depth in the core, coincident with a return of sedge-dominated substrate in the moat core.

The charcoal peaks and remains observed in the peatland and moat cores indicate that fire is a frequent disturbance in this region. Though we have only measured the peaks in macroscopic charcoal deposition, we can use these visible charcoal remains to piece together the fire history of this region. Peat accumulation rates were variable across the peatland surface (range $=1-7 \mathrm{~cm}$ growth per year), we therefore attribute the most recent charcoal peaks in the peatland core (at $12 \mathrm{~cm}$ ) and moat core (at $20 \mathrm{~cm}$ ) to ash deposits from the Survey-line fire of 2001. The ages inferred from the radioisotope profiles indicate that the two charcoal peaks at $20-22 \mathrm{~cm}$ and $28-30 \mathrm{~cm}$ depth in the peatland core are likely fallout from historic regional fires that did not directly affect the forest stand adjacent to the permafrost collapse. The charcoal peak at $46 \mathrm{~cm}$ depth could indicate a localized fire; however, the dating is uncertain. The maximum ages of the trees (182, 172 and 169 years old) in the adjacent black spruce stand indicate that the last stand-replacing fire would have been prior to 1821 .

Subtle changes in the diatom assemblages following charcoal peaks suggest that the algal community is sensitive to charcoal deposition and changes in $\mathrm{pH}$. For example, when the change in diatom species abundance are plotted with charcoal with depth in the peatland core, the greatest shift in both charcoal and E. nymanniana are nearly coincident (data not shown). The increase in Eunotia nymanniana (optimal occurrence at $\mathrm{pH}$ of 6.1; Weckström et al., 1997) after charcoal peaks may indicate a response to increasing $\mathrm{pH}$ caused by the flush of nutrients from charcoal deposition. Ash remaining after the fire and leaching of ammonia can increase the soil pH (Smithwick et al., 2005). This change to soil solution chemistry can persist for multiple growing seasons after fire (Certini, 2005). Diatom responses to fire were documented in a core from Siberia in which Rühland et al. (2000) attributed the assemblage shifts to changes in silt influx from the recently denuded catchment. In this study, decreases in bulk density and increases in $\mathrm{C}: \mathrm{N}$ in the peatland core may also indicate a response of the wetland vegetation in addition to diatoms to nutrient flux from charcoal deposits (Figs. 3 and 4).

\subsection{Triggers of collapse}

At our study site in the three growing seasons following the 2001 fire, we observed a $6 \mathrm{~m}$ lateral expansion of the collapse. We also observed compression-wood in the growth rings of trees at the margin of the collapse feature, this suggests ground movement which could be evidence of subsidence since the last stand-replacing fire. We cannot gauge the rate of permafrost degradation that occurred prior to the 2001 fire; however, the extensive permafrost degradation post-fire indicates that fire is an important driver of ecological change in this ecosystem. Given a black spruce forest with a thin active layer growing over ice-rich permafrost, we hypothesize the following sequence for collapse development. After burning of the forest, permafrost thaw due to darker surface albedo, decreased evapotransipration, and loss of insulating organic soils results in the formation of an initial collapse. The lowered landscape, now partially submerged in thaw water, is then colonized by wetland vegetation such as sedges and Sphagnum. Subsequent fire events in the adjacent forest lead to lateral expansion of the collapse. As the collapse expands, wetland vegetation colonizes the newly subsided margins.

While results from this study supports the hypothesis that fire is an important driver of collapse in this ecosystem after isolation from the active floodplain, permafrost degradation and wetland succession likely proceed in the recovery periods between fires. Approximately 5\% of the area between the active floodplain and the extensive fens to the south is collapse, and $80 \%$ of these collapse features are smaller than the bog investigated in this study. If collapses exhibit radial growth in response to fire and climate disturbance, smaller features were likely initiated more recently. The high proportion of small collapse features in this landscape corroborate the findings of (Jorgenson et al., 2001), and suggest accelerated permafrost degradation on the Tanana Floodplain.

\subsection{Future trajectories}

Since carbon accumulation is greater in permafrost collapse scars than in other peat features, future climate warming could lead to increased collapse and peat expansion and greater carbon storage (Camill and Clark, 1998; Robinson and Moore, 2000). If, however, pervasive drying of wetlands occurs, increased storage may be offset by greater aerobic decomposition (Hilbert et al., 2000) or vegetation shifts (Payette and Delwaide, 2004). Carbon accumulation rates estimated in this study, $172 \pm 154 \mathrm{gC} \mathrm{m}^{-2} \mathrm{y}^{-1}$ 
(or $11 \pm 7 \mathrm{~mm} \mathrm{y}^{-1}, \pm$ range) for the Sphagnum dominated portion of the core, though based on uncertain age estimates, are significantly higher than that reported for a similar Sphagnum riparium collapse feature in Western Canada of $25.6 \mathrm{gC} \mathrm{m}^{-2} \mathrm{y}^{-1}$ or $1.56 \mathrm{~mm} \mathrm{y}^{-1}$ (Robinson and Moore, 2000), and for boreal peatlands in general of $21 \mathrm{gC} \mathrm{m}^{-2} \mathrm{y}^{-1}$ (Clymo et al., 1998); however, they are similar to those reported for a permafrost inception in peatland in the European Russian Arctic of $181 \mathrm{gC} \mathrm{m}^{-2} \mathrm{y}^{-1}$ (Oksanen et al., 2001). This young collapse should continue to accumulate carbon unless future warming or permafrost degradation results in drainage of the wetland.

We attribute the negative relationship between growing season air temperature and the detrended tree-ring width index for black spruce growing in the terrestrial portion of the study site (Fig. 8; Wilmking and Myers-Smith, 2008) to drought-inhibited growth. Although this poorly drained forest seems an unlikely candidate to experience significant plant drought stress, the combination of root systems limited by a shallow active layer and rapid fluctuations in the water table may lead to periods of reduced water availability (Dang and Lieffers, 1989). Annual growth in Western Canadian black spruce stands has previously be shown to be negatively correlated with temperature and positively correlated with precipitation (Dang and Lieffers, 1989; Brooks et al., 1998). In Interior Alaskan white spruce (Picea glauca) treering width, ${ }^{13} \mathrm{C}$ and maximum latewood density was shown to be an indicator of tree growth response to temperatureinduced drought stress (Barber et al., 2000). In our study, the observed decreased black spruce growth in warmer growing seasons may indicate reduced success of this forest type with climate warming.

The spatial mosaic of the Tanana Floodplain landscape is formed by fire, permafrost degradation and vegetation succession. If drought conditions do not increase in Interior Alaska, this system will likely continue on a trajectory of fire mediated collapse and peatland expansion. An expansion of wetland could increase carbon storage and methane emissions in this landscape (Turetsky et al., 2000; Vitt et al., 2000; Camill et al., 2001; Myers-Smith, 2005). Results from this study indicate that both the succession from a sedge- to a Sphagnum-dominated wetland and the decrease in the detrended tree-ring width index of black spruce trees surrounding the collapse were coincident with a non-linear climate shift (Fig. 8). This stepwise increase in summer temperature in Interior Alaska in the late 1970s has been attributed to a regime change in the Pacific Decadal Oscillation (?). A significantly drier future climate or the initiation of subsurface drainage could trigger a return to terrestrial vegetation in the collapse and potentially prevent the regeneration of black spruce in the forest after fire, resulting in the development of a novel ecological state such as a steppe-like community (Chapin et al., 2004). Since it is suspected that carbon accumulation is more strongly controlled by vegetation succession than responding directly to climate (Camill et al., 2001), future vegetation succession away from Sphagnum and sedge species could lead to reduced carbon storage in this ecosystem, particularly if decomposition is not nitrogen limited (Mack et al., 2004).

In this study, we combine paleo-ecological tools including soil chemical analysis, diatom and plant macrofossil analysis, and tree ring data. By combining these different techniques we can begin to piece together the mechanisms driving succession and project future scenarios in this permafrost landscape. Paleo-ecological records are powerful techniques for inferring past climate (Blackford, 2000). With uncertain future climate scenarios, we must continue to expand paleoecological studies utilizing all tools available including diatoms, testate amoeba, plant macrofossils, stable and radio isotopes. By refining our understanding of the influence of the disturbance regime over succession and spatial patterning, we can continue to improve projections of ecological feedbacks to climate change in boreal wetlands.

Acknowledgements. Jill Bubier assisted in the reconnaissance and site selection when we formed the fire-based hypothesis for permafrost collapse and we thank her for her valuable insight. We thank Kathleen Rühland for valuable help with peat diatom preparation and identification; John Barron, Elizabeth Fourtanier, and Morgan Peterson for assistance with diatom procedures, identification and literature; Jamie Hollingsworth, Merritt Turetsky, Kaarle Strailey, and Dan Ulliassi for field and laboratory assistance; Juul Limpens, Martin Evans, Kathleen Rühland, Lesliegh Anderson, John Barron, Evan Kane, Jon O'Donnell, Nick Lizusso and two anonymous referees for their helpful reviews of the manuscript. This research was funded by the USGS Earth Surface Dynamics Program and the Bonanza Creek LTER (Long-Term Ecological Research) program (funded jointly by NSF grant DEB-0423442 and USDA Forest Service, Pacific Northwest Research Station grant PNW01-JV11261952-231).

Edited by: J. Leifeld

\section{References}

Appleby, P.G. and Oldfield, F.: Chapter 21, Application of ${ }^{210} \mathrm{~Pb}$ to sedimentation studies, in: Uranium-series Disequilibrium: Application to Earth, Marine, and Environmental Sciences, edited by: Ivanovich, M. and Harmon, R. S., Clarendon Press, Oxford, 731-778, 1992.

Apps, M. J., Kurz, W. A., Luxmoore, R. J., Nilsson, L. O., Sedjo, R. A., Schmidt, R., Simpson, L. G., and Vinson, T. S.: Boreal forests and tundra, Water Air Soil Poll., 70, 39-53, 1993.

Barber, V. A., Juday, G. P., and Finney, B. P.: Reduced growth of Alaskan white spruce in the twentieth century from temperatureinduced drought stress, Nature, 405, 668-673, 2000.

Barber, V. A., Juday, G. P., Finney, B. P. and Wilmking, M.: Reconstruction of summer temperatures in Interior Alaska from tree ring proxies: Evidence for changing synoptic climate regimes, Clim. Change, 63, 91-120, 2004.

Blackford, J.: Paleoclimatic records from peat bogs, Trends in Ecol. Evol., 15, 193-198, 2000. 
Brooks, J. R., Flanagan, L. B., and Ehleringer, J. R.: Responses of boreal conifers to climate fluctuations: indications from treering widths and carbon isotope analyses, Can. J. Forest Res., 28, 524-533, 1998 .

Camill, P.: Permafrost thaw accelerates in boreal peatlands during late 20th century climate warming, Clim. Change, 68, 135-152, 2005.

Camill, P. and Clark J. S.: Climate change disequilibrium of boreal permafrost peatlands caused by local processes, Am. Nat., 151, 207-222, 1998.

Camill, P. and Clark J. S.: Long-term perspectives on lagged ecosystem response to climate change: permafrost in boreal peatlands and the grassland/woodland boundary, Ecosystems, 3, 534-544, 2000

Camill, P., Lynch, J. A., Clark, J. S., Adams, J. B., and Jordan, B.: Changes in biomass, aboveground net primary production, and peat accumulation following permafrost thaw in the boreal peatlands of Manitoba, Canada, Ecosystems, 4, 461-478, 2001.

Certini, G.: Effects of fire on properties of forest soils: a review, Oecologia, 143, 1-10, 2005.

Chapin, F. S. , McGuire, A. D., Randerson, J., Peilke, R., Baldocchi, D., Hobbie, S. E., Roulet, N., Eugster, W., Kasischke, E., Fastetter, E. B., Zimov, S. A., and Running, S. W.: Arctic and boreal ecosystems of western North America as components of the climate system, Glob. Change Biol., 6, 211-223, 2000.

Chapin, F. S., Callaghan, T. V., Bergeron, Y., Fukuda, M., Johnstone, J. F., Juday, G., and Zimov, S. A.: Global change and the boreal forest: thresholds, shifting states or gradual change?, Ambio, 33, 361-365, 2004.

Christensen, T. R., Johansson, T., Åkerman, H. J., and Mastepanov, M.: Thawing sub-arctic permafrost: Effects on vegetation and methane emissions, Geophys. Res. Lett. 31(1-4), L04501, doi:10.1029/2003GL018680, 2004.

Clymo, R. S., Turunen, J., and Tolonen, K.: Carbon accumulation in peatland, Oikos, 81, 368-388, 1998.

Dang, Q. L. and Lieffers V. J.: Climate and annual ring growth of black spruce in some Alberta peatlands, Can. J. Botany, 67, 1885-1889, 1989.

Foged, N.: Diatoms in Alaska, Bibliotheca Phycologica Band 53, J. Cramer Verlag, Vaduz, Germany, 1981.

Fuller, C. C., van Geen, A., Baskaran, M., Anima, R. J.: Sediment chronology in San Francisco Bay, defined by ${ }^{210} \mathrm{~Pb},{ }^{234} \mathrm{Th}$, ${ }^{137} \mathrm{Cs}, 239,{ }^{240} \mathrm{Pu}$, Mar. Chem., 64, 7-27, 1999.

Gorham, E.: Northern peatlands: role in the carbon cycle and probable responses to climatic warming, Ecol. Appl., 1, 182-195, 1991.

Harden, J. W., Trumbone, S. E., Stocks, B. J., Hirsch, A., Gower, S. T., O'Neill, K. P., and Kasischke, E. S.: The role of fire in the boreal carbon budget, Glob. Change Biol., 6, 174-184, 2000.

Hilbert, D. A., Roulet N. T., and Moore T. R.: Modelling and analysis of peatlands as dynamical systems, J. Ecol., 88, 230-242, 2000.

Jorgenson, M. T., Racine, C. H., Walters, J. C., and Osterkamp, T. E.: Permafrost degradation and ecological changes associated with a warming climate in central Alaska, Climatic Change, 48, 551-579, 2001

Jorgenson, M. T. and Osterkamp, T. E.: Response of boreal ecosystems to varying modes of permafrost degradation, Can. J. Forest Res., 35, 2100-2111, 2005.
Keyser, A. R., Kimball, J. S., Nemani, R. R., and Running, S. W.: Simulating the effects of climate change on the carbon balance of North American high-latitude forests, Glob. Change Biol., 6, 185-195, 2000.

Kienel, U., Siegert, C., and Hahne, J.: Late quaternary paloeoenvironmental reconsructions from a permafrost sequence (North Siberian Lowland, SE Taymyr Peninsula)-a multidisciplinary case study, Boreas, 28, 181-193, 1999.

Krammer, K. and Lange-Bertalot, H.: Bacillariophyceae, in: Süßwasserflora von Mitteleuropa, Vol. 2(1-4), edited by: Ettl, H., Gerloff, J., Heynig, H., and Mollenhauer D., Fischer, Stuttgart, Germany, 1986-1991.

Kuhry, P.: The role of fire in the development of Sphagnum dominated peatlands in western boreal Canada, J. Ecol., 82, 899-910, 1994.

Mack, M. C., Schuur, E. A. G., Bret-Harte, M. S., Shaver, G. R., and Chapin, F. S.: Ecosystem carbon storage in arctic tundra reduced by long-term nutrient fertilization, Nature, 431, 440-443, 2004.

Mantua, N. J., Hare, S. R., Zhang, Y., Wallace, J. M., and Francis, R. C.: A Pacific interdecadal climate oscillation with impacts on salmon production, B. Am. Meteorol. Soc., 78, 1069-1079, 1997.

Moser, K. A., Korhola, A., Weckström, J., Blom, T., Pienitz, R., Smol, J. P., Douglas, M. S. V., and Hay, M. B.: Paleohydrology inferred from diatoms in northern latitude regions, J. Paleolimnol., 24, 93-107, 2000.

Myers-Smith, I. H.: Carbon exchange and permafrost collapse: Implications for a changing climate, Masters Thesis, Department of Biology and Wildlife, University of Alaska Fairbanks, USA 2005.

Myers-Smith, I. H, McGuire, A. D., Harden, J. W., and Chapin, F. S. III. The influence of disturbance on carbon exchange in a permafrost collapse and adjacent burned forest, J. Geophys. Res.Bio, 112, G04017, doi:10.1029/2007JG000423, 2007.

Oksanen, P. O., Kuhry, P., Alekseeva, R. N.: Holocene development of the Rogovaya River peat plateau, European Russian Arctic, The Holocene, 11, 25-40, 2001.

Oldfield, F., Richardson, N., and Appleby, P. G.: Radiometric dating $\left(\mathrm{Pb}^{-210}, \mathrm{Cs}^{137}, \mathrm{Am}^{-241}\right)$ of recent ombrotrophic peat accumulation and evidence for changes in mass-balance, Holocene, 5, 141-8, 1995.

Osterkamp, T. E. and Romanovsky, V. E.: Evidence for warming and thawing of discontinuous permafrost in Alaska, Permafrost Periglac., 10, 17-37, 1999.

Osterkamp, T. E., Viereck, L., Shur, Y., Jorgenson, M. T., Racine, C., Doyle, A., and Boone, R. D.: Observations of thermokarst and its impact on boreal forests in Alaska, USA, Arctic Alpine Res., 32, 303-315, 2000.

Payette, S. and Delwaide, A.: Dynamics of subarctic wetland forests over the past 1500 years, Ecol. Monogr., 74, 373-391, 2004.

Riordan, B., Verbyla, D., and McGuire, A. D.: Shrinking ponds in subarctic Alaska based on 1950-2002 remotely sensed images, J. Geophy. Res., 111, G04002, doi:10.1029/2005JG000150, 2006.

Robinson, S. D. and Moore, T. R.: The influence of permafrost and fire upon carbon accumulation in high boreal peatlands, Northwest Territories, Canada, Arct. Antarct. Alp. Res., 32, 155-166, 2000.

Rühland, K., Smol, J. P., and Warner, B. G.: Response of diatoms 
and other siliceous indicators to the developmental history of a peatland in the Tiksi Forest, Siberia, Russia, Arct. Antarct. Alp. Res., 32, 167-178, 2000.

Serreze, M. C., Walsh, J. E., Chapin, F. S., Osterkamp, T., Dyurgerov, M., Romanovsky, V., Oechel, W. C., Morrison, J., Zhang, T., and Barry, R. G.: Observational Evidence of Recent Change in the Northern High-Latitude Environment, Climatic Change, 46, 159-207, 2000.

Smithwick, E. A. H., Turner M. G., Mack M. C., and Chapin F. S.: Post-fire soil $\mathrm{N}$ cycling in northern conifer forests affected by severe, stand-replacing wildfires, Ecosystems, 8, 163-181, 2005.

Stocks, B. J., Fosberg, M. A., Lynham, T. J., Mearns, L., Wotton, B. M., Yang, Q., Jin, J. Z., Lawrence, K., Hartley, G. R., Mason, J. A., and McKenney, D. W.: Climate Change and Forest Fire Potential in Russian and Canadian Boreal Forests, Climatic Change, 38, 1-13, 1998.

Stuiver, M. and Polach, H.: Discussion of reporting of C data, Arctic Radiocarbon, 19, 355-63, 1977.

Swanson, D. K.: Susceptibility of permafrost soils to deep thaw after forest fires in Interior Alaska, U.S.A., and some ecological implications, Arctic Alpine Res., 28, 217-227, 1996.

Thie, J.: Distribution and thawing of permafrost in the southern part of the discontinuous permafrost zone in Manitoba, Arctic, 27, 189-200, 1974.

Turetsky, M. R., Wieder, R. K., Williams, C. J., and Vitt, D. H.: Organic matter accumulation, peat chemistry, and permafrost melting in peatlands of boreal Alberta, Ecoscience, 7, 379-392, 2000.

Turetsky, M. R., Wieder, R. K., Halsey, L. A., and Vitt, D. H.: Current disturbance and the diminishing peatland carbon sink, Geophys. Res. Lett., 29, 1526, doi:10.1029/2001GL014000, 2002 a.

Turetsky, M. R., Wieder, R. K., and Vitt, D. H.: Boreal peatland $\mathrm{C}$ fluxes under varying permafrost regimes, Soil Biol. Biochem., 34, 907-912, 2002b.

Turetsky, M. R., Manning, S. W., and Wieder, R. K.: Dating recent peat deposits, Wetlands, 24, 324-356, 2004.
Turetsky, M. R., Wieder, R. K., Vitt, D. H., Evans, R. J., and Scott, K. D.: The disappearance of relict permafrost in boreal North America: Effects on peatland carbon storage and fluxes, Glob. Change Biol., 13(9), 1922-1934, doi:10.1111/j.13652486.2007.01381.x, 2007.

Turunen, J., Tomppo, E., Tolonen, K., and Reinikainen, A.: Estimating carbon accumulation rates of undrained mires in Finland - application to boreal and subarctic regions, Holocene, 12, 6980, 2002.

Van Dam, H., Mertens, A., and Sinkeldam, J.: A coded checklist and ecological indicator values of freshwater diatoms from the Netherlands, Neth. J. Aquat. Ecol., 28, 117-133, 1994.

Vitt, D. H., Halsey, L. A., and Zoltai, S. C.: The changing landscape of Canada's western boreal forest: the current dynamics of permafrost, Can. J. Forest Res., 30, 283-287, 2000.

Weckström, J., Korhola, A., and Blom, T.: Diatoms as quantitative indicators of $\mathrm{pH}$ and water temperature in subarctic Fennoscandian lakes, Hydrobiologia, 347, 171-184, 1997.

Wilmking, M., Juday, G. P., Barber, V. A., and Zald, H. S. J.: Recent climate warming forces contrasting growth responses of white spruce at treeline in Alaska through temperature thresholds, Glob. Change Biol., 10, 1724-1736, 2004.

Wilmking, M. and Myers-Smith, I. H.: Changing climate sensitivity of black spruce (Picea mariana) in a peatland-forest landscape in Interior Alaska, Dendrochronologia, 25, 165-175, 2008.

Wrona, F. J., Prowse, T. D., and Reist, J. D.: Chapter 8: Freshwater ecosystems and fisheries, in: Arctic Climate Impact Assessment: Impacts of a Warming Arctic, edited by: Hassol, S. L., Cambridge University Press, Cambridge, United Kingdom, 353-452, 2004.

Yoshikawa, K., Bolton, W. R., Romanovsky, V. E., Fukuda, M., and Hinzman, L. D.: Impacts of wildfire on the permafrost in the boreal forests of Interior Alaska, J. Geophy. Res., 108, 81488162. 2003.

Zoltai, S. C.: Cyclic development of permafrost in the peatlands of northwestern Alberta, Arctic Alpine Res., 25, 240-246, 1993.

Zoltai, S. C. and Vitt, D. H.: Canadian wetlands: environmental gradients and classification, Plant Ecol., 118, 131-137, 1995. 